\title{
Opiate addiction and cocaine addiction: underlying molecular neurobiology and genetics
}

\author{
Mary Jeanne Kreek, Orna Levran, Brian Reed, Stefan D. Schlussman, \\ Yan Zhou, and Eduardo R. Butelman
}

Laboratory of the Biology of Addictive Diseases, The Rockefeller University, New York, New York, USA.

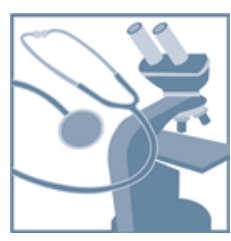

Addictive diseases, including addiction to heroin, prescription opioids, or cocaine, pose massive personal and public health costs. Addictions are chronic relapsing diseases of the brain caused by drug-induced direct effects and persisting neuroadaptations at the epigenetic, mRNA, neuropeptide, neurotransmitter, or protein levels. These neuroadaptations, which can be specific to drug type, and their resultant behaviors are modified by various internal and external environmental factors, including stress responsivity, addict mindset, and social setting. Specific gene variants, including variants encoding pharmacological target proteins or genes mediating neuroadaptations, also modify vulnerability at particular stages of addiction. Greater understanding of these interacting factors through laboratory-based and translational studies have the potential to optimize early interventions for the therapy of chronic addictive diseases and to reduce the burden of relapse. Here, we review the molecular neurobiology and genetics of opiate addiction, including heroin and prescription opioids, and cocaine addiction.

Addiction was historically viewed as a disease of "weak personality" and was not systematically addressed by the scientific and medical communities until the latter half of the 20th century. Pioneering studies in the 1960s and 1970s led to the development of methadone, the first (and still effective and widely used) treatment for the long-term management of addictions to heroin and other opiates (1-3). During the 1980s, efforts coalesced around the investigation and development of pharmacological treatments for other drugs of abuse, including alcohol and cocaine, though there are still no approved medications for the treatment of cocaine addiction. Addictions are now commonly accepted as diseases of the brain caused by the impact of the drug itself on the brain (direct effects and neuroadaptations) and modified by various environmental factors. These factors include epigenetic changes, addict mindset, and social influences, including peer pressure, family environment, and especially, response to stress and stressors (see below). Further, the presence of specific variants of multiple genes may enhance or decrease the vulnerability to developing specific addictions. These gene variants may function synergistically with genetic polymorphisms involved in common comorbid conditions, such as anxiety or depression, and stress responsivity. Addictions can also be comorbid with major infectious disorders, such as HIV/AIDS (4).

This review focuses on current information about the molecular neurobiology and genetics of opiate addiction, including heroin and prescription opiates, and cocaine addiction, with an emphasis on the opioid receptor system (with MOP-r, KOP-r, and DOP-r receptors) and neuropeptides ( $\beta$-endorphin $[\beta-\mathrm{EP}]$, dynorphins, and enkephalins) and interaction with dopaminergic systems.

\section{Neurobiology of addiction to MOP-r agonists or cocaine}

Heroin and prescription opioids, such as oxycodone or hydrocodone (e.g., OxyContin and Vicodin, respectively) act primarily as MOP-r agonists with relatively short duration of action, whereas

Conflict of interest: The authors have declared that no conflict of interest exists. Citation for this article: J Clin Invest. 2012;122(10):3387-3393. doi:10.1172/JCI60390. cocaine (and other stimulants, e.g., methamphetamine) act primarily to increase synaptic dopamine by inhibition of dopamine reuptake or an increase in release. Activation in the dopaminergic mesocortico/mesolimbic and nigrostriatal systems, either directly in the case of cocaine or indirectly for heroin/prescription opioids or alcohol, appears to be a common neurobiological consequence of exposure to drugs of abuse (5-7).

After these initial effects of drugs of abuse on dopaminergic systems, there are short-term and long-term regulatory changes at the mRNA or protein/peptide level in major neurotransmitter and neuropeptide systems (8-12). It is hypothesized that these long-term regulatory changes, which persist even after prolonged drug-free periods, underlie the chronic relapsing nature of addictive diseases. Chronic exposure to drugs of abuse, including heroin and cocaine, induces upregulation of the KOP-r/dynorphin system. Such an endogenous activation of KOP-r tone by dynorphins is thought to underlie aversion, dysphoria/anhedonia, and depression-like or anxiety-like neuropsychiatric states. Such a counterregulatory action by the KOP-r/dynorphin system may therefore mediate, in part, the negatively reinforcing aspects of withdrawal from drugs of abuse and may exacerbate the chronic relapsing nature of addictive diseases.

Most currently approved therapeutic agents in drug or alcohol addiction pharmacotherapy (i.e., methadone, buprenorphine, and naltrexone) are opioid receptor ligands (Figure 1). Opioid receptor mechanisms are also involved in the rewarding effects of alcohol, for which a direct pharmacodynamic target is yet to be unequivocally identified. For example, MOP-r-knockout mice exhibit less alcohol-induced reward (13). Also, one of the major medications approved for the treatment of alcoholism, naltrexone, has prominent MOP-r antagonist effects and also has affinity for KOP-r receptors (14). Stress-responsive brain areas and the hypothalamo-pituitary-adrenal (HPA) axis are also involved at particular stages of the addiction trajectory to cocaine, heroin/ prescription opioids, and alcohol or recovery therefrom (15-18). The impact of these stress-related systems on addiction neurobiology will be discussed separately below. 


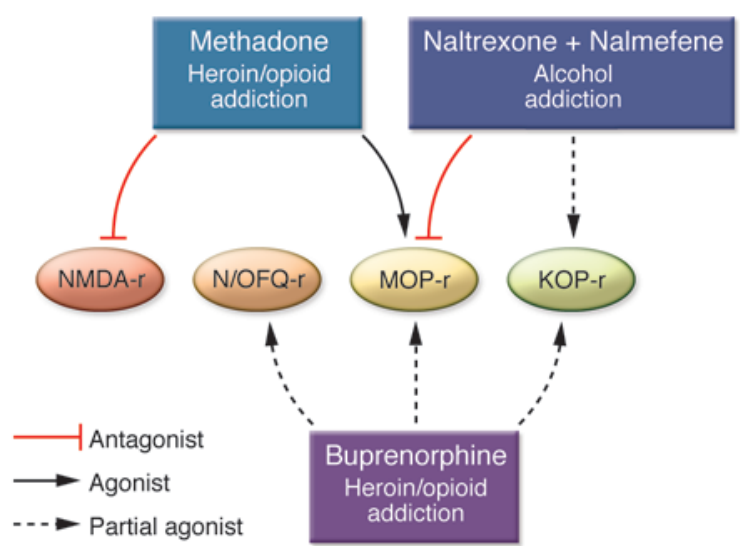

\section{Cocaine}

The neuroanatomical localization of the immediate effects of cocaine overlap with those of the MOP-r agonists, with the nucleus accumbens (NAc) having been the most intensively studied region, as this region is thought to play an important role in the initial rewarding effects of cocaine. Other regions, including the caudate-putamen, may be involved in longer-term changes occurring in cocaine-induced addictive states. The main acute effect of cocaine is an increase in extracellular dopamine levels. Binge cocaine administration, the typical use pattern in cocaine abusers, results in successive "spikes" of dopamine concentration, as shown in animal models (19-21). Increased extracellular dopamine in dopaminergic mesocorticolimbic and nigrostriatal dopaminergic terminal fields plays a critical role in the effects of cocaine and addiction to cocaine. Dopaminergic circuitry is regulated bidirectionally by the endogenous opioid system (22); MOP-r activation results in release of dopamine $(23,24)$, whereas KOP-r activation is inhibitory, lowering extracellular dopamine levels (25).

We have observed increases in the levels of MOP-r in the NAc as well as in the dorsal striatum (caudate-putamen) after chronic cocaine exposure in rodent models (26). We also observed increases in KOP-r levels in the caudate-putamen and in other brain regions, including the ventral tegmental area, where the dopaminergic neurons projecting to the NAc are located (27). Changes in opioid receptor levels observed following cocaine use continue to be observed during abstinence, indicating long-term perturbations in the endogenous opioid system $(28,29)$. In vivo PET imaging in the brains of cocaine-addicted patients likewise shows an increase in the binding potential of MOP-r (30).

The persistent effects of cocaine on the endogenous opioid receptor/neuropeptide system, as well as the bidirectional regulation by MOP-r and KOP-r on the dopaminergic system, indicate the possibility of opioid agents as therapeutics for cocaine addiction. We have investigated this possibility in rat models, finding that methadone is effective in preventing cocaine-induced conditioned place preference (CPP, a model indicative of reward) as well as cocaine-induced neuroadaptations $(31,32)$. Importantly, similar findings have been observed in humans: cocaine-addicted patients in methadone or buprenorphine maintenance treatment use less cocaine $(33,34)$.

Naltrexone (a potent MOP-r antagonist which also has considerable affinity at KOP-r) is approved for the treatment of alcoholism and has had some effectiveness in reducing cocaine use in alcoholic patients (35). These dual-addiction diagnosis patients

\section{Figure 1}

Most pharmacotherapies currently approved for the treatment of addictive disorders target MOP-r. The full MOP-r agonist methadone is approved in the chronic maintenance treatment of addiction to heroin or prescription opioids, as is the MOP-r partial agonist buprenorphine. Naltrexone, also approved as an i.m. monthly depot formulation (e.g., for the treatment of alcoholism, and more recently for the prevention of relapse to opioid dependence following detoxification), has powerful MOP-r antagonist effects. Of interest, both buprenorphine and naltrexone also have affinity at KOP-r, and buprenorphine is also a partial agonist at orphanin $\mathrm{FQ} /$ nociceptin receptors (N/OFQ-r), with relatively low potency.

may provide a particular challenge, both clinically and for study design and interpretation. Of interest, naltrexone was effective in reducing use of amphetamine (another psychostimulant compound acting through the dopamine transporter) in patients without cooccurring alcoholism (36).

The KOP-r/dynorphin system has emerged as a potential therapeutic target for both cocaine and heroin/prescription opioid addiction (see also below). Centrally active KOP-r high-efficacy agonists are generally psychotomimetic with aversive properties. In rodent models of early relapse (reinstatement models), KOP-r antagonists prevented stress-induced reinstatement of cocaine-seeking behavior, although these antagonists did not block cocaine-induced reinstatement (37-39). KOP-r partial agonists can be hypothesized as a pharmacotherapeutic strategy for cocaine addiction and relapse (40). A partial agonist causes a submaximal response in comparison with full agonists, such as the endogenous KOP-r ligands, the dynorphins (41). A KOP-r partial agonist could therefore provide partial receptor tone in situations in which endogenous ligand is relatively deficient, but prevent overactivation of the KOP-r receptor system when the dynorphins are present at high levels. Thus, a selective KOP-r partial agonist could prevent stress-induced activation of KOP-r, contributing to relapse while also providing required homeostatic countermodulation of dopaminergic systems $(25,37,42)$. Current clinically available ligands with KOP-r partial agonist effects (e.g., butorphanol or nalbuphine) are not selective, as they also display considerable MOP-r-mediated effects.

To date, no pharmacotherapeutic intervention in the treatment of cocaine addiction has been successfully developed. Current efforts in this regard target the endogenous opioid system, both with currently available compounds and potential new compounds with desired opioid receptor selectivity/activation profiles.

\section{Heroin and prescription opioids}

Abuse of illicit opiates continues to be a serious public health concern. According to the 2011 Monitoring the Future report, 1.2\% of high school students in the USA reported lifetime use of heroin (43). Approximately $13 \%$ of high school seniors also reported nonmedical use of "other narcotic drugs," such as the prescription opioids oxycodone and hydrocodone (44).

The main active metabolites of heroin and abused prescription opioids act primarily as agonists at MOP-r. Heroin (diacetylmorphine) enters the brain quickly and in high concentrations. Once in the brain, heroin is rapidly converted to the biologically active 
metabolites morphine and monoacetylmorphine (45). These compounds bind MOP-r (e.g., on interneurons in the substantia nigra and ventral tegmental area) and relieve GABAergic inhibition of dopaminergic neurons (46). This results in release of dopamine into the projection fields $(5,24)$, where it interacts with pre- and postsynaptic dopaminergic receptors. A substantial portion of MOP-r agonists' rewarding effects and addiction potential may thus be related to this downstream activation in dopaminergic fields. In animal studies modeling human abuserelated exposure to MOP-r agonists, several molecular regulatory changes were detected in components of the endogenous opioid receptor/neuropeptide and dopaminergic systems (47-50). These changes may be part of functional alterations postulated to underlie in part the chronic relapsing nature of heroin/prescription opioid addiction. Consistent with observations in human heroin abusers, we have shown that one inbred strain of rats escalated their self administration when given long-term (14-day), long-access (18-hour/day) availability of heroin (51), consistent with a genetic predisposition. Of potential translational importance, a recent article has suggested that high preexisting levels of Pdyn mRNA in the NAc (observed in a mouse strain) may protect against the acquisition of morphine-induced CPP (52). This suggests that high KOP-r/dynorphin tone may be protective at particular stages of addiction trajectory.

We have used siRNAs to demonstrate the critical role of the MOP-r in the substantia nigra and ventral tegmental area (where cell bodies for the nigrostriatal and mesolimbic dopaminergic systems are located) on heroin-induced rewarding effects (53). siRNA directed toward the mouse Oprm1 or GFP (as a control) were infused bilaterally into mouse midbrain dopaminergic areas. This siRNA infusion significantly reduced Oprm $1 \mathrm{mRNA}$ levels and MOP-r-binding density in these regions and also reduced the locomotor response to heroin and heroin-induced CPP (53). These data highlight the critical role of midbrain MOP-r in mediating behavioral and rewarding effects of heroin and also demonstrate the utility of region-specific targeted siRNAs in the neurobiological study of specific components of the reward system. Repeated preexposure to the widely abused prescription opioid oxycodone results in a sustained decrease in basal striatal dopamine dialysate levels in adult and adolescent mice (e.g., up to at least one week of withdrawal) (23). This is supportive of long-lasting adaptations in this crucial dopaminergic end point in the context of repeated exposure to and prolonged withdrawal from a prescription opioid.

\section{Stress systems in the neurobiology of addictions}

In humans, stress plays a major role in drug addiction and elevates drug craving. Stress-induced HPA activity predicted relapse to drug use and amounts of subsequent use, indicating that stress not only elicits craving, but also independently predicts relapse (54).

In the HPA axis, stress increases both corticotropin-releasing factor (CRF) and arginine-vasopressin (AVP) release into the pituitary portal circulation from terminals of hypothalamic paraventricular nucleus (PVN). Both CRF-R1 and AVP-V1b receptors are located on corticotropes in the anterior pituitary and drive the processing and release of ACTH and $\beta$-EP from the pro-opiomelanocortin (POMC) peptide, of particular interest for the field of addictive diseases $(55,56)$. Endogenous opioids are critical in the control of the HPA axis. Animal and human studies have demonstrated that $\beta$-EP and dynorphin exert tonic inhibition and stimu- lation of HPA activity acting on MOP-r and KOP-r, respectively. In a rat study, either acute morphine or acute stress elevated HPA activity; in contrast, acute morphine blunted the HPA activation by stress, suggesting a counterregulatory role of opiates on the stress response (57). Both ACTH and cortisol levels are significantly disrupted in active heroin addicts; however, both basal activity and responsivity of the HPA axis are normalized in steady-state methadone-maintained patients (58). Rodent studies using pump infusion have confirmed that steady-state methadone does not alter HPA responsivity $(31,32,59,60)$. Morphine tolerance develops to the initial stimulatory effect, following long-term treatment $(12,61)$. Tolerance to MOP-r or KOP-r agonists, but no cross tolerance, is observed, suggesting the development of MOP-ror KOP-r-specific tolerance (61).

Unlike the inhibitory effect of MOP-r agonists, cocaine stimulates HPA activity in humans. After a challenge dose of cocaine, ACTH response is significantly lower in cocaine-dependent men than in occasional cocaine users, indicating that attenuation of cocaine's effects occurs after chronic cocaine use (62). Some human studies found that cocaine-addicted patients show higher basal plasma ACTH and cortisol levels at even up to three months of abstinence (for example, ref. 63); however, other studies have found no difference during abstinence in basal ACTH and cortisol levels (for example, refs. 18, 62). Notably, CRF or stress-induced HPA responses predict amounts of subsequent drug use in relapse, though the HPA hormonal increases are part of the nonspecific activation associated with psychological stress $(54,64)$, Furthermore, cocaine addicts are associated with HPA hyperresponsivity to glucocorticoid-negative feedback removal by metyrapone (18). In rats, cocaine rapidly elevates plasma ACTH and corticosterone levels, mediated by CRF and dopamine transmission (65-67). The HPA hormones in response to chronic cocaine show a significant attenuation compared with the acute effects, indicating tolerance of HPA activity to chronic cocaine (65). In early (1-2 day) cocaine withdrawal, there is a slight, but significant, increase in HPA hormones $(68,69)$. During protracted withdrawal from chronic escalating-dose (but not steady-dose) "binge" cocaine, enhanced AVP/V1b expression was associated with persistent elevations of HPA activity (56).

Increased CRF activity in the central nucleus of the amygdala (CeA) underlies the anxiogenic and stress-like consequences of withdrawal common to many drugs of abuse $(68,70)$. Activation of CeA CRF may play a role in reward deficits and dysphoria (71). CRF-R1 antagonists attenuate stress-induced reinstatement of cocaine or heroin seeking in rats (72). Administration of CRF to cocaine-addicted patients induced stress responses and subsequent cocaine craving (64).

Central AVP binds to two G protein-coupled receptor subtypes: V1a and V1b, both highly expressed in the rat extended amygdala. AVP-V1b receptors are expressed prominently in the amygdala, PVN, and hippocampus (73). Activation of V1b receptor pathways in the amygdala is an important step in the neurobiology of stress-related behaviors, including anxiogenic and depressive behaviors in rodents (74). We reported that amygdalar Avp gene expression levels were increased in acute heroin withdrawal, and a systemically active and highly selective AVP-V1b receptor antagonist dose-dependently blocked stress-induced reinstatement of heroin-seeking behavior $(11,75)$. Using genetically selected Sardinian alcohol-preferring rats, we further found that pharmacological blockade of AVP-V1b receptor attenuated alcohol drinking (76). 
Together, these data suggest that the AVP-V1b system may be an important component of the neural circuitry contributing to drug withdrawal as well as drug-seeking and -taking behaviors.

The opioid peptide $\beta$-EP (primarily a MOP-r agonist) is distributed in the hypothalamus and mesocorticolimbic regions, including the NAc. Because activation of MOP-r by $\beta$-EP is rewarding and modulates the NAc dopamine release (77), $\beta$-EP may be involved in the reinforcing effects of drugs of abuse (78). Compounds with MOP-r antagonist effects reduced the acquisition of cocaine selfadministration behavior or CPP $(79,80)$, further raising the possibility that opioid neuropeptides play a functional role in the actions of cocaine at particular stages of addiction trajectory. Indeed, cocaine CPP is blunted in $\beta$-EP-deficient mice (81).

\section{The genetics of drug addictions}

Genetic factors contribute to the vulnerability to developing drug addictions and to interindividual variability in the treatment efficacy for drug addiction (82). Polymorphisms in several genes, including genes encoding opioid receptors and ligands, were indicated in association with drug addiction (82-84). Here, we specifically discuss studies of the MOP-r gene (OPRM1), heroin addiction, and methadone maintenance treatment (MMT) for opioid addiction.

Two OPRM1 SNPs (17C>T and 118A>G) encode amino acid substitutions. The most studied OPRM1 variant is $118 \mathrm{~A}>\mathrm{G}$ (rs1799971), which causes the replacement of an asparagine residue by aspartic acid. This change results in removal of an N-glycosylation site in the extracellular domain, which in turn results in a higher affinity binding of $\beta$-EP than the prototype, altered receptor-binding site availability, and signaling efficacy as well as reduced mRNA levels (85-89). The $118 \mathrm{G}$ allele is most common in Asian populations (40\%-50\%), has moderate frequency in European populations $(15 \%-30 \%)$, and has very low prevalence in African populations. Two mouse models of $118 \mathrm{~A}>\mathrm{G}$ show lower antinociceptive response and reward properties of morphine, reduction in the aversive effect of naloxone-precipitated morphine withdrawal, in a sex-dependent manner (90), reduction in N-linked glycosylation and protein stability (91), and greater dopamine response to an alcohol challenge (92).

A large number of association studies of SNP 118A>G have been reported and reviewed $(93,94)$. In two studies from this laboratory, the $118 \mathrm{G}$ variant was associated with alcoholism and heroin addiction in a sample of Swedish subjects with little genetic admixture $(95,96)$. The $118 \mathrm{G}$ allele has been associated with phenotypes including opioid dependence and other substance dependencies, alcoholism, attenuated HPA axis response to stress, and reduced clinical effects of opioid analgesics, although findings were not always consistent $(86,97-99)$. The mixed results may be explained in part by different haplotype patterns between populations. In a recent analysis (100), we showed that the 118G allele is positioned within a haplogroup in a population-specific manner and is in high linkage disequilibrium (LD) with several distant variants that may have a regulatory effect. Several studies showed a positive effect of the $118 \mathrm{G}$ allele on treatment response to the opioid antagonist naltrexone (101). The $118 \mathrm{G}$ allele was associated with a robust cortisol response to the MOP-r competitive antagonist naloxone in a population-specific manner (102-105). The $118 \mathrm{G}$ allele blunted the ACTH response to metyrapone in healthy subjects (106).

Carriers of the $118 \mathrm{G}$ allele show an elevated sensitivity to pain and reduced analgesic response to opioids. Homozygotes for the
$118 \mathrm{G}$ allele requested higher doses of oral morphine in treatment for cancer pain. Results of several studies suggest that the effect of the $118 \mathrm{G}$ allele may vary among different opioids, different routes of drug administration, or different pain etiologies, as recently reviewed (107).

SNP $17 \mathrm{C}>\mathrm{T}$ (rs1799971) results in an alanine-to-valine substitution in the N-terminal and is found mostly in populations with African ancestry. The TT genotype was associated with quantitative measures of substance use in African American women (108). Additional non-coding OPRM1 SNPs have been indicated in drug addiction and response to drugs, including intronic variants (109-111) and a variant in the 5' region near the gene (112), but their function is yet unknown.

\section{Pharmacogenetics of methadone maintenance treatment}

One goal of pharmacogenetics is to develop individualized therapy in response to interindividual variability in drug response. Methadone is a full MOP-r agonist and a weak NMDA receptor antagonist (Figure 1). Predicting individual sensitivity to methadone may help determine the most effective methadone dose. Methadone metabolism is attributed primarily to cytochrome P450 enzymes CYP3A4, CYP2B6, and CYP2D6. Methadone is a substrate of the ATP-binding cassette efflux transporter P-glycoprotein.

Several pharmacogenetics studies have aimed to identify genetic factors that modulate response to methadone maintenance (Table 1). We have identified three genes that may modulate response to methadone maintenance in a well-characterized sample from Israel. The ABCB1 synonymous SNP 1236C > T (rs1128503) was associated with higher methadone doses (>150 mg/d) (113). Subjects homozygous for the variant alleles of the functional CYP2B6 SNPs $785 \mathrm{~A}>\mathrm{G}(\mathrm{rs} 2279343)$ and $516 \mathrm{G}>\mathrm{T}(\mathrm{rs} 3745274)\left(C Y P 2 B 6^{*} 6\right.$ allele) require lower doses than those of heterozygotes and noncarriers (114). An intronic SNP with unknown function (rs2239622) in the gene-encoding nerve growth factor ( $\beta$ polypeptide) (NGFB) that is involved in neural plasticity, memory, and behavior was shown to be associated with relatively low methadone doses (115).

\section{Table 1}

Genes associated with MMT response

$\begin{array}{lcc}\text { Gene } & \text { Definition } & \begin{array}{c}\text { Selected } \\ \text { ref. }\end{array} \\ \text { ABCB1 } & \text { ATP-binding cassette, sub-family B } & 113,117 \\ \text { (MDR/TAP), 1 } & \\ \text { ARRB2 } & \text { beta-arrestin 2 } & 118 \\ \text { BDNF } & \text { brain-derived neurotrophic factor } & 119 \\ \text { CYP2B6 } & \text { cytochrome P450, family 2, } & 114,117 \\ & \text { subfamily B, polypeptide 6 } \\ \text { CYP2D6 } & \text { cytochrome P450, family 2, } \\ & \text { subfamily D, polypeptide 6 } \\ \text { DRD2/ANKK1 } & \text { dopamine D2 receptor/ankyrin repeat } & 120 \\ & \text { and kinase domain containing 1 } \\ \text { GRM6 } & \text { metabotropic glutamate receptor } & 117,121, \\ \text { KCNJ6 } & \text { potassium inwardly rectifying channel } & 123 \\ \text { MYOCD } & \text { Myocardin } & 124 \\ \text { NGFB } & \text { nerve growth factor (beta polypeptide) } & 123 \\ \text { OPRM1 } & \text { mu opioid receptor } & 115 \\ & & 117\end{array}$




\section{Summary and conclusion}

Drug-induced effects and neuroadaptations, specific genetic variants, and environmental factors all contribute to the development of specific addictive diseases. It is therefore essential to conduct laboratory-based studies and translational studies to determine the molecular neurobiology and genetic factors contributing to addictions, including the role of functional gene variants and epigenetic changes. The goal is to increase and optimize early interventions for the therapy of chronic addictive diseases that are extraordinarily costly in terms of human life, productivity, and expense to society (116).

\section{Acknowledgments}

The authors gratefully acknowledge funding from the NIHNational Institute on Drug Abuse (P60-DA05130 to M.J. Kreek and R21-DA031990 to B. Reed).

Address correspondence to: Mary Jeanne Kreek, Laboratory of the Biology of Addictive Diseases, The Rockefeller University, 1230 York Ave., Box 171, New York, New York 10065, USA. Phone: 212.327.8490; Fax: 212.327.8574; E-mail: kreek@ rockefeller.edu.
1. Dole VP, Nyswander ME, Kreek MJ. Narcotic blockade. Arch Intern Med. 1966;118(4):304-309.

2. Kreek MJ. Medical safety and side effects of methadone in tolerant individuals. JAMA. 1973; 223(6):665-668.

3. Kreek MJ. Methadone-related opioid agonist pharmacotherapy for heroin addiction. History, recent molecular and neurochemical research and future in mainstream medicine. Ann N Y Acad Sci. 2000;909:186-216

4. Novick DM, Khan I, Kreek MJ. Acquired immunodeficiency syndrome and infection with hepatitis viruses in individuals abusing drugs by injection. Bull Narc. 1986;38(1-2):15-25.

5. Di Chiara G, Imperato A. Drugs abused by humans preferentially increase synaptic dopamine concentrations in the mesolimbic system of freely moving rats. Proc Natl Acad Sci US A. 1988;85(14):5274-5278.

6. Maisonneuve IM, Kreek MJ. Acute tolerance to the dopamine response induced by a binge pattern of cocaine administration in male rats: an in vivo microdialysis study. J Pharmacol Exp Ther. 1994; 268(2):916-921.

7. Pettit HO, Ettenberg A, Bloom FE, Koob GF. Destruction of dopamine in the nucleus accumbens selectively attenuates cocaine but not heroin self-administration in rats. Psychopharmacology (Berl). 1984;84(2):167-173.

8. Tsukada $\mathrm{H}$, et al. Effects of binge pattern cocaine administration on dopamine D1 and D2 receptors in the rat brain: an in vivo study using positron emission tomography. J Neurosci. 1996; 16(23):7670-7677.

9. Spangler R, Zhou Y, Maggos CE, Zlobin A, Ho A, Kreek MJ. Dopamine antagonist and 'binge' cocaine effects on rat opioid and dopamine transporter mRNAs. Neuroreport. 1996;7(13):2196-2200.

10. Volkow ND, et al. Effects of chronic cocaine abuse on postsynaptic dopamine receptors. Am J Psychiatry. 1990;147(6):719-724

11. Zhou Y, Leri F, Cummins E, Hoeschele M, Kreek $\mathrm{MJ}$. Involvement of arginine vasopressin and V1b receptor in heroin withdrawal and heroin seeking precipitated by stress and by heroin. Neuropsychopharmacology. 2008;33(2):226-236.

12. Zhou Y, Bendor J, Hofmann L, Randesi M, Ho A, Kreek MJ. Mu opioid receptor and orexin/hypocretin mRNA levels in the lateral hypothalamus and striatum are enhanced by morphine withdrawal. J Endocrinol. 2006;191(1):137-145.

13. Hall FS, Sora I, Uhl GR. Ethanol consumption and reward are decreased in mu-opiate receptor knockout mice. Psychopharmacology (Berl). 2001; 154(1):43-49.

14. Peng X, Knapp BI, Bidlack JM, Neumeyer JL. Pharmacological properties of bivalent ligands containing butorphan linked to nalbuphine, naltrexone, and naloxone at mu, delta, and kappa opioid receptors. J Med Chem. 2007;50(9):2254-2258.

15. O'Malley SS, Krishnan-Sarin S, Farren C, Sinha R, Kreek MJ. Naltrexone decreases craving and alcohol self-administration in alcohol-dependent subjects and activates the hypothalamo-pituitaryadrenocortical axis. Psychopharmacology (Berl). 2002;
160(1):19-29.

16. Fox HC, Talih M, Malison R, Anderson GM, Kreek MJ, Sinha R. Frequency of recent cocaine and alcohol use affects drug craving and associated responses to stress and drug-related cues. Psychoneuroendocrinology. 2005;30(9):880-891.

17. Schluger JH, Bart G, Green M, Ho A, Kreek MJ. Corticotropin-releasing factor testing reveals a dosedependent difference in methadone maintained vs control subjects. Neuropsychopharmacology. 2003; 28(5):985-994.

18. Schluger JH, Borg L, Ho A, Kreek MJ. Altered HPA axis responsivity to metyrapone testing in methadone maintained former heroin addicts with ongoing cocaine addiction. Neuropsychopharmacology. 2001;24(5):568-575.

19. Maisonneuve IM, Ho A, Kreek MJ. Chronic administration of a cocaine "binge" alters basal extracellular levels in male rats: an in vivo microdialysis study. J Pharmacol Exp Ther. 1995;272(2):652-657.

20. Zhang Y, Schlussman SD, Ho A, Kreek MJ. Effect of acute binge cocaine on levels of extracellular dopamine in the caudate putamen and nucleus accumbens in male C57BL/6J and 129/J mice. Brain Res. 2001;923(1-2):172-177.

21. Zhang Y, Schlussman SD, Ho A, Kreek MJ. Effect of chronic "binge cocaine" on basal levels and cocaineinduced increases of dopamine in the caudate putamen and nucleus accumbens of C57BL/6J and 129/J mice. Synapse. 2003;50(3):191-199.

22. Di Chiara G, Imperato A. Opposite effects of mu and kappa opiate agonists on dopamine release in the nucleus accumbens and in the dorsal caudate of freely moving rats. J Pharmacol Exp Ther. 1988; 244(3):1067-1080.

23. Zhang Y, Picetti R, Butelman ER, Schlussman SD, Ho A, Kreek MJ. Behavioral and neurochemical changes induced by oxycodone differ between adolescent and adult mice. Neuropsychopharmacology. 2009;34(4):912-922.

24. Spanagel R, Herz A, Shippenberg TS. The effects of opioid peptides on dopamine release in the nucleus accumbens: an in vivo microdialysis study. J Neurochem. 1990;55(5):1734-1740.

25. Zhang Y, Butelman ER, Schlussman SD, Ho A, Kreek MJ. Effect of the endogenous kappa opioid agonist dynorphin $\mathrm{A}(1-17)$ on cocaine-evoked increases in striatal dopamine levels and cocaineinduced place preference in C57BL/6J mice. Psychopharmacology (Berl). 2004;172(4):422-429.

26. Unterwald EM, Horne-King J, Kreek MJ. Chronic cocaine alters brain mu opioid receptors. Brain Res. 1992;584(1-2):314-318

27. Unterwald EM, Rubenfeld JM, Kreek MJ. Repeated cocaine administration upregulates kappa and $\mathrm{mu}$, but not delta, opioid receptors. Neuroreport. 1994;5(13):1613-1616.

28. Bailey A, Gianotti R, Ho A, Kreek MJ. Downregulation of kappa-opioid receptors in basolateral amygdala and septum of rats withdrawn for 14 days from an escalating dose "binge" cocaine administration paradigm. Synapse. 2007;61(10):820-826.

29. Bailey A, Gianotti R, Ho A, Kreek MJ. Persistent upregulation of mu-opioid, but not adenosine, receptors in brains of long-term withdrawn escalating dose "binge" cocaine-treated rats. Synapse. 2005; 57(3):160-166.

30. Zubieta JK, Gorelick DA, Stauffer R, Ravert HT, Dannals RF, Frost JJ. Increased mu opioid receptor binding detected by PET in cocaine-dependent men is associated with cocaine craving. Nat Med. 1996; 2(11):1225-1229.

31. Leri F, Zhou Y, Goddard B, Cummins E, Kreek MJ. Effects of high-dose methadone maintenance on cocaine place conditioning, cocaine self-administration, and mu-opioid receptor mRNA expression in the rat brain. Neuropsychopharmacology. 2006; 31(7):1462-1474

32. Leri F, Zhou Y, Goddard B, Levy A, Jacklin D, Kreek MJ. Steady-state methadone blocks cocaine seeking and cocaine-induced gene expression alterations in the rat brain. Eur Neuropsychopharmacol. 2009; 19(4):238-249.

33. Peles E, Kreek MJ, Kellogg S, Adelson M. High methadone dose significantly reduces cocaine use in methadone maintenance treatment (MMT) patients. J Addict Dis. 2006;25(1):43-50.

34. Montoya ID, et al. Randomized trial of buprenorphine for treatment of concurrent opiate and cocaine dependence. Clin Pharmacol Ther. 2004; 75(1):34-48.

35. Ahmadi J, Kampman KM, Oslin DM, Pettinati HM, Dackis C, Sparkman T. Predictors of treatment outcome in outpatient cocaine and alcohol dependence treatment. Am J Addict. 2009;18(1):81-86.

36. Jayaram-Lindstrom N, Hammarberg A, Beck $\mathrm{O}$, Franck J. Naltrexone for the treatment of amphetamine dependence: a randomized, placebo-controlled trial. Am J Psychiatry. 2008; 165(11):1442-1448.

37. Beardsley PM, Howard JL, Shelton KL, Carroll FI. Differential effects of the novel kappa opioid receptor antagonist, JDTic, on reinstatement of cocaine-seeking induced by footshock stressors vs cocaine primes and its antidepressant-like effects in rats. Psychopharmacology (Berl). 2005; 183(1):118-126.

38. Chefer VI, Czyzyk T, Bolan EA, Moron J, Pintar JE, Shippenberg TS. Endogenous kappa-opioid receptor systems regulate mesoaccumbal dopamine dynamics and vulnerability to cocaine. J Neurosci. 2005;25(20):5029-5037.

39. Redila VA, Chavkin C. Stress-induced reinstatement of cocaine seeking is mediated by the kappa opioid system. Psychopharmacology (Berl). 2008; 200(1):59-70.

40. Kreek MJ, LaForge KS, Butelman E. Pharmacotherapy of addictions. Nat Rev Drug Discov. 2002; 1(9):710-726.

41. Zhu BT. Mechanistic explanation for the unique pharmacologic properties of receptor partial agonists. Biomed Pharmacother. 2005;59(3):76-89.

42. Chartoff E, Sawyer A, Rachlin A, Potter D, Pliakas A, Carlezon WA. Blockade of kappa opioid receptors attenuates the development of depressive-like behaviors induced by cocaine withdrawal in rats. Neuropharmacology. 2012;62(1):167-176.

43. Johnston LD, O’Malley PM, Bachman JG, Schulen- 
berg JE. Monitoring The Future National Survey Results On Drug Use, 1975-2010. Vol. 1: Secondary School Students. Ann Arbor, Michigan, USA: Institute for Social Research, The University of Michigan; 2011.

44. McCabe SE, West BT, Teter CJ, Boyd CJ. Medical and nonmedical use of prescription opioids among high school seniors in the United States [published online ahead of print May 7, 2012]. Arch Pediatr Adolesc Med. doi:10.1001/archpediatrics.2012.85.

45. Inturrisi CE, Schultz M, Shin S, Umans JG, Angel L, Simon EJ. Evidence from opiate binding studies that heroin acts through its metabolites. Life Sci. 1983; 33(suppl 1):773-776.

46. Johnson SW, North RA. Opioids excite dopamine neurons by hyperpolarization of local interneurons. J Neurosci. 1992;12(2):483-488.

47. Schlussman SD, Cassin J, Zhang Y, Levran O, Ho A, Kreek MJ. Regional mRNA expression of the endogenous opioid and dopaminergic systems in brains of C57BL/6J and 129P3/J mice: strain and heroin effects. Pharmacol Biochem Behav. 2011;100(1):8-16.

48. Turchan J, Przewłocka B, Toth G, Lason W, Borsodi A, Przewłocki R. The effect of repeated administration of morphine, cocaine and ethanol on mu and delta opioid receptor density in the nucleus accumbens and striatum of the rat. Neuroscience. 1999; 91(3):971-977.

49. Turchan J, Lason W, Budziszewska B, Przewlocka B. Effects of single and repeated morphine administration on the prodynorphin, proenkephalin and dopamine D2 receptor gene expression in the mouse brain. Neuropeptides. 1997;31(1):24-28.

50. Beitner-Johnson D, Nestler EJ. Morphine and cocaine exert common chronic actions on tyrosine hydroxylase in dopaminergic brain reward regions. J Neurochem. 1991;57(1):344-347.

51. Picetti R, Caccavo JA, Ho A, Kreek MJ. Dose escalation and dose preference in extended-access heroin self-administration in Lewis and Fischer rats. Psychopharmacology (Berl). 2012;220(1):163-172.

52. Gieryk A, Ziolkowska B, Solecki W, Kubik J, Przewlocki R. Forebrain PENK and PDYN gene expression levels in three inbred strains of mice and their relationship to genotype-dependent morphine reward sensitivity. Psychopharmacology (Berl). 2010; 208(2):291-300.

53. Zhang Y, et al. Mu opioid receptor knockdown in the substantia nigra/ventral tegmental area by synthetic small interfering RNA blocks the rewarding and locomotor effects of heroin. Neuroscience. 2009; 158(2):474-483.

54. Sinha R, Garcia M, Paliwal P, Kreek MJ, Rounsaville BJ. Stress-induced cocaine craving and hypothalamic-pituitary-adrenal responses are predictive of cocaine relapse outcomes. Arch Gen Psychiatry. 2006; 63(3):324-331.

55. Vale W, Spiess J, Rivier C, Rivier J. Characterization of a 41-residue ovine hypothalamic peptide that stimulates secretion of corticotropin and betaendorphin. Science. 1981;213(4514):1394-1397.

56. Zhou Y, Litvin Y, Piras AP, Pfaff DW, Kreek MJ. Persistent Increase in hypothalamic arginine vasopressin gene expression during protracted withdrawal from chronic escalating-dose cocaine in rodents. Neuropsychopharmacol. 2011;36(10):2062-2075.

57. Zhou Y, et al. Hypothalamic-pituitary-adrenal activity and pro-opiomelanocortin mRNA levels in the hypothalamus and pituitary of the rat are differentially modulated by acute intermittent morphine with or without water restriction stress. J Endocrinol. 1999;163(2):261-267.

58. Kreek MJ, Ragunath J, Plevy S, Hamer D, Schneider B, Hartman N. ACTH, cortisol and beta-endorphin response to metyrapone testing during chronic methadone maintenance treatment in humans. Neuropeptides. 1984;5(1-3):277-278.

59. Zhou Y, Spangler R, Maggos CE, LaForge KS, Ho A, Kreek MJ. Steady-state methadone in rats does not change mRNA levels of corticotropin-releasing factor, its pituitary receptor or proopiomelanocortin. Eur J Pharmacol. 1996;315(1):31-35.

60. Leri F, Zhou Y, Carmichael B, Cummins E, Kreek MJ. Treatment-like steady-state methadone in rats interferes with incubation of cocaine sensitization and associated alterations in gene expression. Eur Neuropsychopharmacol. 2012;22(2):143-152.

61. Ignar DM, Kuhn CM. Effects of specific mu and kappa opiate tolerance and abstinence on hypothalamo-pituitary-adrenal axis secretion in the rat. J Pharmacol Exp Ther. 1990;255(3):1287-1295.

62. Mendelson JH, Sholar M, Mello NK, Teoh SK, Sholar JW. Cocaine tolerance: behavioral, cardiovascular, and neuroendocrine function in men. Neuropsychopharmacology. 1998;18(4):263-271.

63. Wilkins JN, et al. DHEAS and POMS measures identify cocaine dependence treatment outcome. Psychoneuroendocrinology. 2005;30(1):18-28.

64. Brady KT, et al. Response to corticotropin-releasing hormone infusion in cocaine-dependent individuals. Arch Gen Psychiatry. 2009;66(4):422-430.

65. Zhou Y, Spangler R, LaForge KS, Maggos CE, Ho A, Kreek MJ. Corticotropin-releasing factor and type 1 corticotropin-releasing factor receptor messenger RNAs in rat brain and pituitary during "binge"pattern cocaine administration and chronic withdrawal. JPharmacol Exp Ther. 1996;279(1):351-358.

66. Spangler R, Zhou Y, Schlussman SD, Ho A, Kreek MJ. Behavioral stereotypies induced by 'binge' cocaine administration are independent of druginduced increases in corticosterone levels. Behav Brain Res. 1997;86(2):201-204.

67. Rivier C, Vale W. Cocaine stimulates adrenocorticotropin (ACTH) secretion through a corticotropinreleasing factor (CRF)-mediated mechanism. Brain Res. 1987;422(2):403-406.

68. Zhou Y, Spangler R, Ho A, Kreek MJ. Increased CRH mRNA levels in the rat amygdala during short-term withdrawal from chronic 'binge' cocaine. Brain Res Mol Brain Res. 2003;114(1):73-79.

69. Zhou Y, Spangler R, Schlussman SD, Ho A, Kreek MJ. Alterations in hypothalamic-pituitary-adrenal axis activity and in levels of proopiomelanocortin and corticotropin-releasing hormone-receptor 1 mRNAs in the pituitary and hypothalamus of the rat during chronic 'binge' cocaine and withdrawal. Brain Res. 2003;964(2):187-199.

70. Weiss F. Neurobiology of craving, conditioned reward and relapse. Curr Opin Pharmacol. 2005; 5(1):9-19.

71. Kreek MJ, Koob GF. Drug dependence: stress and dysregulation of brain reward pathways. Drug Alcohol Depend. 1998;51(1-2):23-47.

72. Shaham Y, Erb S, Stewart J. Stress-induced relapse to heroin and cocaine seeking in rats: a review. Brain Res Brain Res Rev. 2000;33(1):13-33.

73. Lolait SJ, et al. Extrapituitary expression of the rat V1b vasopressin receptor gene. Proc Natl Acad Sci US A. 1995;92(15):6783-6787.

74. Griebel G, et al. Anxiolytic- and antidepressant-like effects of the non-peptide vasopressin V1b receptor antagonist, SSR149415, suggest an innovative approach for the treatment of stress-related disorders. Proc Natl Acad Sci U S A. 2002;99(9):6370-6375.

75. Zhou Y, Bendor JT, Yuferov V, Schlussman SD, Ho A, Kreek MJ. Amygdalar vasopressin mRNA increases in acute cocaine withdrawal: evidence for opioid receptor modulation. Neuroscience. 2005; 134(4):1391-1397.

76. Zhou Y, Colombo G, Carai MA, Ho A, Gessa GL, Kreek MJ. Involvement of arginine vasopressin and $\mathrm{V} 1 \mathrm{~b}$ receptor in alcohol drinking in Sardinian alcohol-preferring rats. Alcohol Clin Exp Res. 2011; 35(10):1876-1883.

77. Spanagel R, Herz A, Bals-Kubik R, Shippenberg TS Beta-endorphin-induced locomotor stimulation and reinforcement are associated with an increase in dopamine release in the nucleus accumbens. Psychopharmacology (Berl). 1991;104(1):51-56.

78. Koob G, Kreek MJ. Stress, dysregulation of drug reward pathways, and the transition to drug dependence. Am J Psychiatry. 2007;164(8):1149-1159.

79. Houdi AA, Bardo MT, Van Loon GR. Opioid mediation of cocaine-induced hyperactivity and reinforcement. Brain Res. 1989;497(1):195-198.

80. Ramsey NF, van Ree JM. Intracerebroventricular naltrexone treatment attenuates acquisition of intravenous cocaine self-administration in rats. Pharmacol Biochem Behav. 1991;40(4):807-810.

81. Marquez P, Baliram R, Dabaja I, Gajawada N, Lutfy K. The role of beta-endorphin in the acute motor stimulatory and rewarding actions of cocaine in mice. Psychopharmacology (Berl). 2008; 197(3):443-448.

82. Kreek MJ, Bart G, Lilly C, LaForge KS, Nielsen DA. Pharmacogenetics and human molecular genetics of opiate and cocaine addictions and their treatments. Pharmacol Rev. 2005;57(1):1-26.

83. Yuferov V, Levran O, Proudnikov D, Nielsen DA, Kreek MJ. Search for genetic markers and functional variants involved in the development of opiate and cocaine addiction and treatment. Ann NY Acad Sci. 2010;1187:184-207.

84. Levran O, Yuferov V, Kreek MJ. The genetics of the opioid system and specific drug addictions. Hum Genet. 2012;131(6):823-842.

85 . Bond C, et al. Single-nucleotide polymorphism in the human mu opioid receptor gene alters betaendorphin binding and activity: possible implications for opiate addiction. Proc Natl Acad Sci U S A. 1998;95(16):9608-9613.

86. Deb I, Chakraborty J, Gangopadhyay PK, Choudhury SR, Das S. Single-nucleotide polymorphism (A118G) in exon 1 of OPRM1 gene causes alteration in downstream signaling by mu-opioid receptor and may contribute to the genetic risk for addiction. J Neurochem. 2010;112(2):486-496.

87. Zhang Y, Wang D, Johnson AD, Papp AC, Sadee W. Allelic expression imbalance of human mu opioid receptor (OPRM1) caused by variant A118G. J Biol Chem. 2005;280(38):32618-32624.

88. Beyer A, Koch T, Schroder H, Schulz S, Hollt V. Effect of the A118G polymorphism on binding affinity, potency and agonist-mediated endocytosis, desensitization, and resensitization of the human mu-opioid receptor. J Neurochem. 2004; 89(3):553-560.

89. Kroslak T, Laforge KS, Gianotti RJ, Ho A, Nielsen DA, Kreek MJ. The single nucleotide polymorphism A118G alters functional properties of the human mu opioid receptor. J Neurochem. 2007; 103(1):77-87.

90. Mague SD, Isiegas C, Huang P, Liu-Chen LY, Lerman C, Blendy JA. Mouse model of OPRM1 (A118G) polymorphism has sex-specific effects on drugmediated behavior. Proc Natl Acad Sci U S A. 2009; 106(26):10847-10852.

91. Huang P, Chen C, Mague SD, Blendy JA, Liu-Chen LY. A common single nucleotide polymorphism A118G of the mu opioid receptor alters its N-glycosylation and protein stability. Biochem J. 2012; 441(1):379-386.

92. Ramchandani VA, et al. A genetic determinant of the striatal dopamine response to alcohol in men. Mol Psychiatry. 2011;16(8):809-817.

93. Mague SD, Blendy JA. OPRM1 SNP (A118G): involvement in disease development, treatment response, and animal models. Drug Alcohol Depend. 2010;108(3):172-182.

94. Ray LA, Barr CS, Blendy JA, Oslin D, Goldman $\mathrm{D}$, Anton RF. The role of the Asn40Asp polymorphism of the mu opioid receptor gene (OPRM1) on alcoholism etiology and treatment: A critical review. Alcohol Clin Exp Res. 2012;36(3):385-394.

95. Bart G, et al. Substantial attributable risk related 
to a functional mu-opioid receptor gene polymorphism in association with heroin addiction in central Sweden. Mol Psychiatry. 2004;9(6):547-549.

96. Bart G, et al. Increased attributable risk related to a functional mu-opioid receptor gene polymorphism in association with alcohol dependence in central Sweden. Neuropsychopharmacology. 2005; 30(2):417-422.

97. Oertel BG, et al. A common human micro-opioid receptor genetic variant diminishes the receptor signaling efficacy in brain regions processing the sensory information of pain. J Biol Chem. 2009; 284(10):6530-6535.

98. Kapur S, Sharad S, Singh RA, Gupta AK. A118g polymorphism in mu opioid receptor gene (oprm1): association with opiate addiction in subjects of Indian origin. J Integr Neurosci. 2007; 6(4):511-522.

99. Glatt SJ, et al. Evaluation of OPRM1 variants in heroin dependence by family-based association testing and meta-analysis. Drug Alcohol Depend. 2007; 90(2-3):159-165.

100.Levran O, Awolesi O, Linzy S, Adelson M, Kreek MJ. Haplotype block structure of the genomic region of the mu opioid receptor gene.J Hum Genet. 2011;56(2):147-155.

101. Sturgess JE, George TP, Kennedy JL, Heinz A, Muller DJ. Pharmacogenetics of alcohol, nicotine and drug addiction treatments. Addict Biol. 2011; 16(3):357-376.

102. Chong RY, Oswald L, Yang X, Uhart M, Lin PI, Wand GS. The mu-opioid receptor polymorphism A118G predicts cortisol responses to naloxone and stress. Neuropsychopharmacology. 2006;31(1):204-211.

103. Hernandez-Avila CA, Wand G, Luo X, Gelernter J, Kranzler HR. Association between the cortisol response to opioid blockade and the Asn40Asp polymorphism at the mu-opioid receptor locus (OPRM1). Am J Med Genet B Neuropsychiatr Genet. 2003;118B(1):60-65.

104. Wand GS, et al. The mu-opioid receptor gene polymorphism (A118G) alters HPA axis activation induced by opioid receptor blockade. Neuropsychopharmacology. 2002;26(1):106-114.

105. Hernandez-Avila CA, Covault J, Wand G, Zhang H, Gelernter J, Kranzler HR. Population-specific effects of the Asn40Asp polymorphism at the mu-opioid receptor gene (OPRM1) on HPA-axis activation. Pharmacogenet Genomics. 2007;17(12):1031-1038.

106. Ducat E, et al. Mu-opioid receptor A118G polymorphism in healthy volunteers affects hypothalamic-pituitary-adrenal axis adrenocorticotropic hormone stress response to metyrapone [published online ahead of print April 20,2011]. Addict Biol. doi:10.1111/j.1369-1600.2011.00313.x.

107. Shi Q, Cleeland CS, Klepstad P, Miaskowski C, Pedersen NL. Biological pathways and genetic variables involved in pain. Qual Life Res. 2010;19(10):1407-1417.

108. Crystal HA, et al. A C17T polymorphism in the $\mathrm{mu}$ opiate receptor is associated with quantitative measures of drug use in African American women. Addict Biol. 2012;17(1):181-191.

109.Levran O, et al. Genetic susceptibility to heroin addiction: a candidate gene association study. Genes Brain Behav. 2008;7(7):720-729.

110.Zhang $\mathrm{H}$, et al. Association between two mu-opioid receptor gene (OPRM1) haplotype blocks and drug or alcohol dependence. Hum Mol Genet. 2006; 15(6):807-819.

111.Zhang D, et al. Effect of mu-opioid receptor gene polymorphisms on heroin-induced subjective responses in a Chinese population. Biol Psychiatry. 2007;61(11):1244-1251.

112. Nielsen DA, et al. Genotype patterns that contribute to increased risk for or protection from developing heroin addiction. Mol Psychiatry. 2008; 13(4):417-428.

113. Levran O, et al. ABCB1 (MDR1) genetic variants are associated with methadone doses required for effective treatment of heroin dependence. Hum Mol Genet. 2008;17(14):2219-2227.

114.Levran O, Peles E, Hamon S, Randesi M, Adelson M, Kreek MJ. CYP2B6 SNPs are associated with methadone dose required for effective treatment of opioid addiction [published online ahead of print July 25, 2011]. Addict Biol. doi:10.1111/j.13691600.2011.00349.x.

115.Levran O, et al. Nerve growth factor beta polypeptide (NGFB) genetic variability: association with the methadone dose required for effective maintenance treatment. Pharmacogenomics J. 2012;12(4):319-327.

116. Kreek MJ. Role of a functional human gene polymorphism in stress responsivity and addictions. Clin Pharmacol Ther. 2008;83(4):615-618.

117. Hung CC, et al. Impact of genetic polymorphisms in ABCB1, CYP2B6, OPRM1, ANKK1 and DRD2 genes on methadone therapy in Han Chinese patients. Pharmacogenomics. 2011;12(11):1525-1533.

118. Oneda B, et al. $\beta$-Arrestin2 influences the response to methadone in opioid-dependent patients. Pharmacogenomics J. 2011;11(4):258-266.

119. de Cid R, et al. BDNF variability in opioid addicts and response to methadone treatment: preliminary findings. Genes Brain Behav. 2008;7(5):515-522.

120. Fonseca F, et al. Contribution of cytochrome P450 and $\mathrm{ABCB} 1$ genetic variability on methadone pharmacokinetics, dose requirements, and response. PLoS One. 2011;6(5):e19527.

121. Doehring A, et al. Genetic variants altering dopamine D2 receptor expression or function modulate the risk of opiate addiction and the dosage requirements of methadone substitution. Pharmacogenet Genomics. 2009;19(6):407-414

122. Lawford BR, et al. The $\mathrm{D}(2)$ dopamine receptor $\mathrm{A}(1)$ allele and opioid dependence: association with heroin use and response to methadone treatment. $A m$ JMed Genet. 2000;96(5):592-598.

123. Fonseca F, et al. Response to methadone maintenance treatment is associated with the MYOCD and GRM6 genes. Mol Diagn Ther. 2010;14(3):171-178.

124.Lotsch J, Pruss H, Veh RW, Doehring A. A KCNJ6 (Kir3.2, GIRK2) gene polymorphism modulates opioid effects on analgesia and addiction but not on pupil size. Pharmacogenet Genomics. 2010; 20(5):291-297. 